ISO 9001:2008 Certified

International Journal of Engineering and Innovative Technology (IJEIT)

Volume 10, Issue 5, November 2020

\title{
An innovated practical system to study in the laboratory the influence of desert sandstorm on solar panels
}

\author{
${ }^{1}$ Abdelkader Nouiri, ${ }^{2}$ Hana Kellil \\ ${ }^{1}$ LMSSEF Laboratory, University of Oum El-Bouaghi, Algeria \\ ${ }^{2}$ University of Khenchela, Algeria
}

\begin{abstract}
The natural problem is the collection of desert dust from $(P V)$ panels (North Africa, Middle East, area of the Gulf and other regions). Research has shown that accumulated dust can reduce solar panel performance, but the findings have not been very clearly quantified. The research will develop a method for evaluating the effects of the accumulation of dust in the production of laboratory solar panels. An artificial system is developed in this research paper (machine). In order to test electricity and efficiency, experiments with a revolutionary developer using artificial dust particles on solar panels have been carried out. The research found that the dust on the surface of the solar panel would reduce the performance of the system by up to 50 percent. The current pressure characteristics are then measured with distinct densities before and during the simulated sandstorm. The results would directly discuss the impact of pollution on the efficiency of solar panels in remote locations (Sahara).
\end{abstract}

Index Terms - Desert environment; solar energy; sandstorm effect; Simulation; photovoltaic technology.

\section{INTRODUCTION}

Renewable energy plays a very important role in power production, especially in developing countries. The sun is a clean, durable, polluting source of energy. In solar power systems, in which the solar photons are absorbed by the semiconductor, energy output is transformed directly into electricity [1]. Solar panels use photovoltaic (PV) panels for converting electricity through sun-radiation into solar energy. A load control and a battery are available on this computer. Sustainable returns can also be obtainable with the appropriate design to maximize solar light (orientation, exposure, and tracer) (electricity). However, these are vulnerable to omnipresent functional features like dust deposition, waste birds and water, often overlooked which can dramatically reduce solar thermal plants' efficiency. The losses of inverter, cabling and soiling module (dust and debris) in module output (PV) systems are further reduced by 10-25,000. Algeria is the largest region in Africa, the largest in the Arab world and the Mediterranean basin.

It has a substantial part of the southern desert climate (Sahara). Algeria has an annual sunset rate of 2000 hours per year [4] while the world energy council and energy ministry of Algeria earn an average of 3,900 hours per year [5].

Manuscript received: 22 October 2020

Manuscript received in revised form: 14 November 2020

Manuscript accepted: 05 December 2020

Manuscript Available online: 15 December 2020
The average solar energy received in the coastal region is $2400 \mathrm{kWh} / \mathrm{m} 2$ a year, $1900 \mathrm{kWh} / \mathrm{m} 2$ annually on the highlands, and $2650 \mathrm{kWh} / \mathrm{m} 2$ annually in Southern Algeria.

This big solar power in northern Africa is adversely affected by the effects of sandstorms on the efficiency of protective solar panels of glass [3]. Sandstorms and dust in desert regions are caused by solar modules. Most of the dust in the region of the Sahara may be non-organic particles, such as particles of dust or other impurities, hanging electrostatically in the dry wind and on the glass area of solar panels. The dust can also be non-organically abrasive minerals (e.g. silica) that damage and scratch the glass surface of the solar modules. Many powdery areas in desert regions are suspended deposits of wind, birds and other animal fossilization, urban pollutants and leaves of organic plant, pollen, etc. The solar panels are wetly dissipated. A study has been carried out on solar panels [7-9] of the effects of sandstorm and dust. The results demonstrate a sharp rugging development, with sand masses increasingly lowering optical transmission. The efficiency of the Solar Panels is decreasing due to these parameters. Sand stroke tends to have a relatively weak impact on solar cell efficiency $(\mathrm{Ef}=0.88)$. Sites produced with grains of sand can also contain particulate matter of dust. The performance of PV panels [10] was also studied; dust has an effect in solar panel performance. The decrease in the maximum power produced depends on the particle density and size [11-16]. Previous research [17, 18] has shown the viability of a $15 \%$ reduction. It has also been shown that the effect of dust, however, has been significantly decreased under increased radiation. In figure 2 of this paper we have created an artificial framework. Analyzing the laboratory effect of sandstorms for various doses on solar panels.

\section{EXPERIMENT APPARATUS AND SETUP}

We used our innovation which is a glass box with dimensions $=78 \mathrm{~cm} \times 78 \mathrm{~cm} \times 78 \mathrm{~cm}$, a solar photovoltaic panel which contain 72 cells $(12 \mathrm{~W})$ as a power for each one) is placed inside the glass box, particles of dust (sand and gypsum) are produced by a prompter (in order to achieve the artificial sandstorm), I-V measurement setup (voltmeter and ampermeter) are connected to solar panel in order to measure the short circuit current (Isc) and open circuit voltage (Voc) and variable resistances are connected to circuit in order to measure current-voltage characteristics. In order to compare 


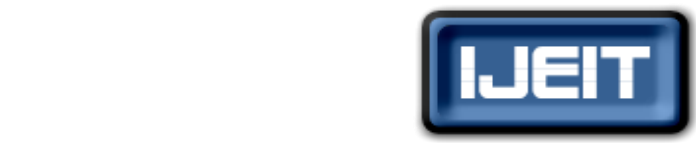

ISSN: 2277-3754

\section{ISO 9001:2008 Certified \\ International Journal of Engineering and Innovative Technology (IJEIT) \\ Volume 10, Issue 5, November 2020}

the performance of the panels before and during the sandstorm, as well as how the performance changed when the density of the dust is increased. The current voltage (I-V) characteristics were measured before, during the sandstorm using a volte meter and ampere meter. The Table 1 and Table 2 summarize the used doses (The volume of sand divided by the volume of the box).

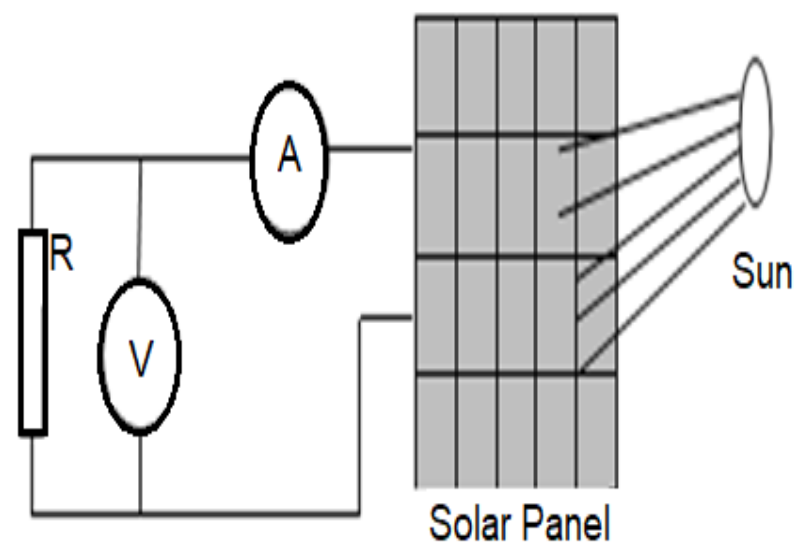

Fig. 1. Schematic representation of I-V measurements

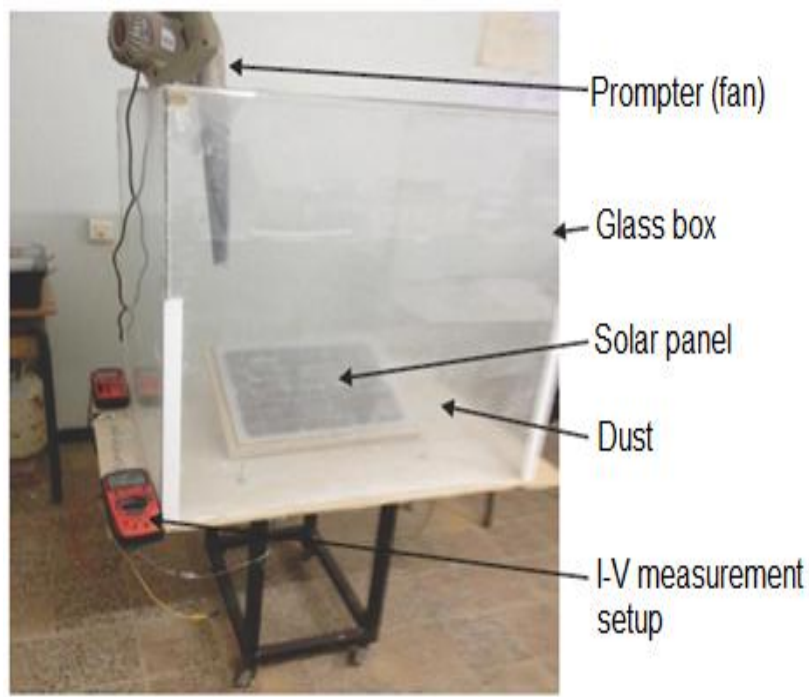

Fig. 2. Artificial system to study the influence of sandstorm on solar panel in laboratory

Table 1. Two different doses of gypsum

The used material is Gypsum

\begin{tabular}{ccc}
\hline Volume used $\left(10^{-5} \mathrm{~m}^{3}\right)$ & 46.15 & 92.32 \\
Dose $(\%)$ & 0.098 & 0.194 \\
\hline
\end{tabular}

Table 2. Two different doses of gypsum + sand

\begin{tabular}{ccc}
\hline \multicolumn{3}{c}{ The used material is Gypsum + sand } \\
\hline Volume used $\left(10^{-5} \mathrm{~m}^{3}\right)$ & 92.32 & 138.5 \\
Dose $(\%)$ & 0.194 & 0.292 \\
\hline
\end{tabular}

\section{RESULTS AND DISCUSSION}

Figure 3 and Figure 4 present qualitative results of an artificial sandstorm. The following images are taken with different doses at various stages of the experiment. It is clear that the photovoltaic panel relies on the dose of sandstorm (the quantities of gypsum and sand). In desert regions where there is a real sandstorm, the same phenomenon can be seen, so it is a true problem requiring scientific analysis and solutions. The influence of dust on photovoltaic panels examining two key parameters has been examined by numerous published papers: Figures 5 and 6 demonstrate our $\mathrm{I}-\mathrm{V}$ measurements. The I-V measurements are clearly reduced with increased doses that affect the strength of the solar panel. In the Middle East and Gulf regions, similar findings were achieved [22]. The short circuit stream (ISC) is tested for various dose levels to assess the decrease in solar panel electricity during the sandstorm (Table 3 and Table 4).
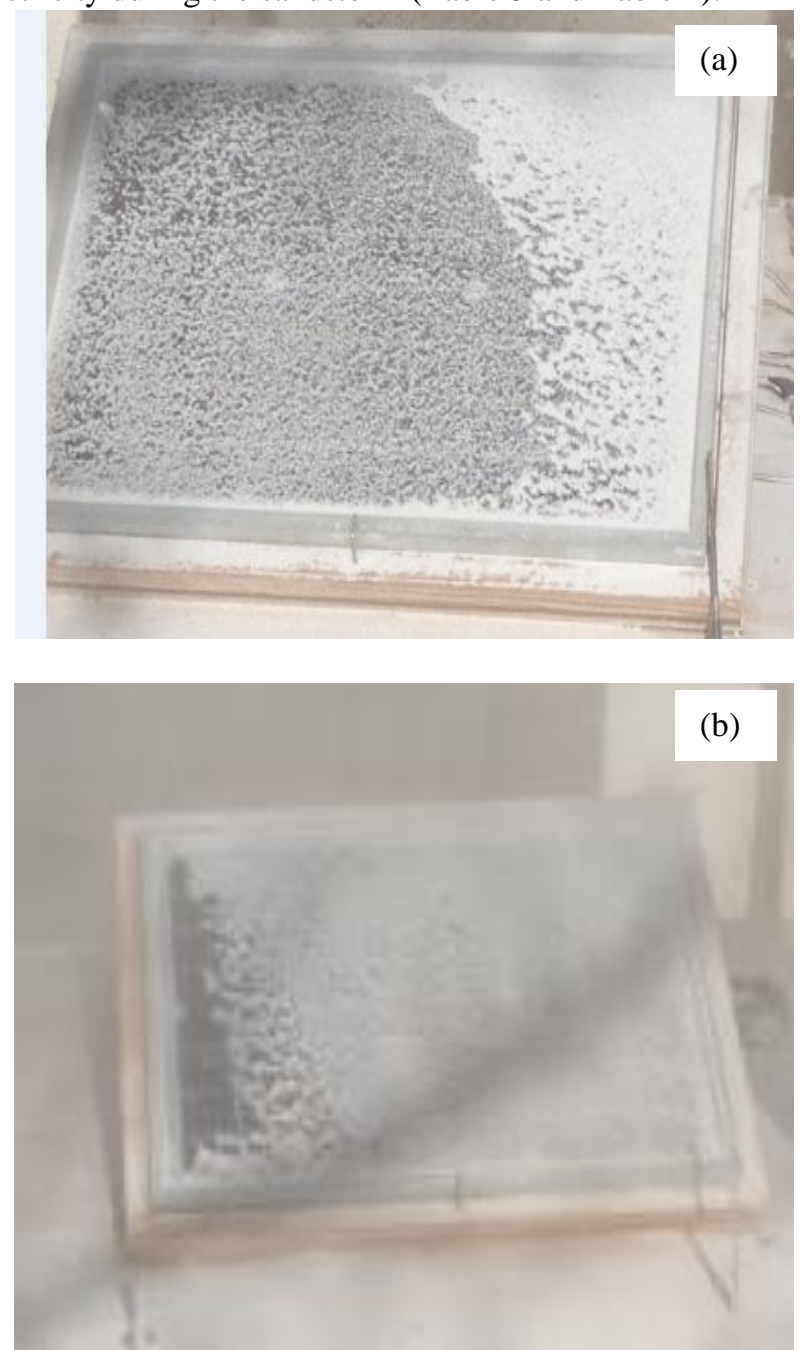

Fig. 3. Experience with gypsum (a- first dose, b- second dose) The variation of the shortcut current under artificial sandstorm is presented in Figure 7. We can see in fig. 7 that the optical transmission decreases regularly with increasing the quantities of dust (doses), also the nature and particle size of dust also influence on solar panel efficiency. The experience with gypsum influence greater than that of gypsum+sand because the grain size of gypsum is less than that of sand, so the gypsum coating is very compact greater than of that of sand, consequently, the gypsum layer obscures the light more than that of sand. 


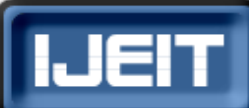

ISSN: 2277-3754

ISO 9001:2008 Certified

International Journal of Engineering and Innovative Technology (IJEIT)

Volume 10, Issue 5, November 2020

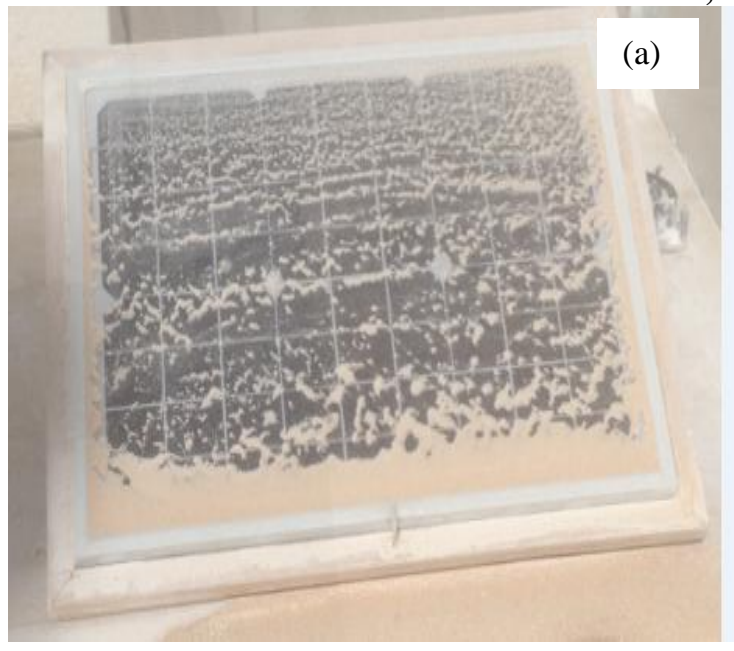

(b)

Fig. 4. Experience with sand and gypsum (a- first dose, bsecond dose)

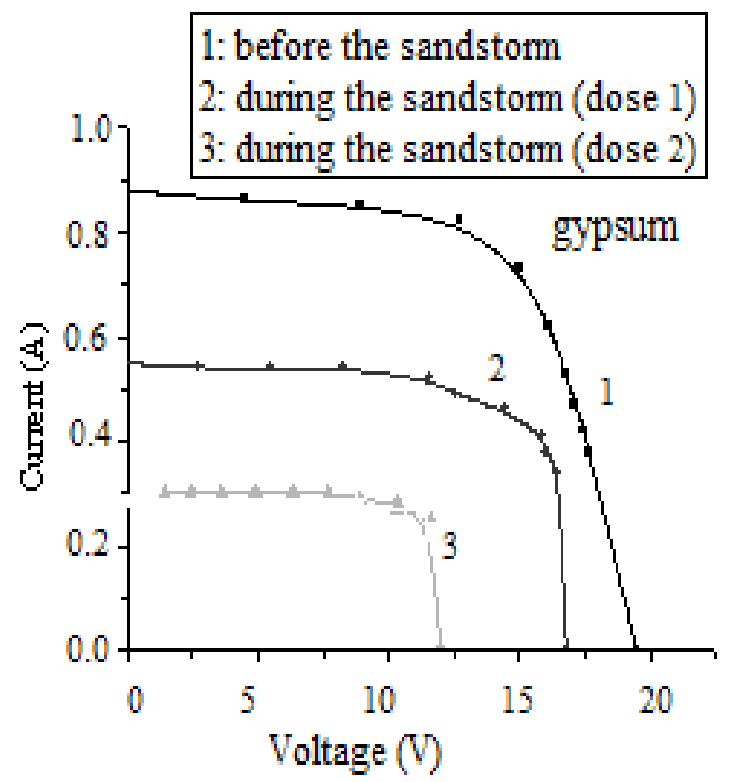

Fig. 5. I-V curves of experience with gypsum using different doses presented in Table 1 (dose $1=0.098 \%$ and dose $2=0.194 \%$ )

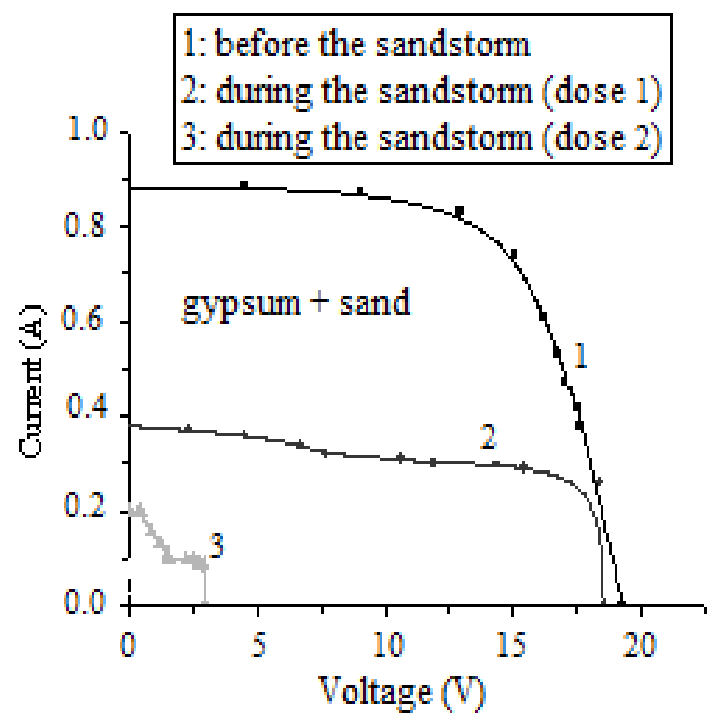

Fig. 6. I-V curves of experience with gypsum and sand using different doses presented in Table $2($ dose $1=0.194 \%$ and dose $2=0.292 \%$ )

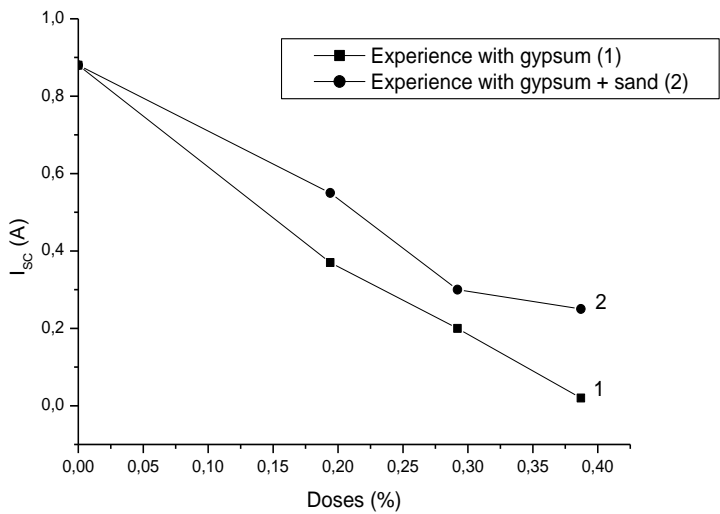

Fig. 7. Variation of $I_{s c}$ as a function of doses of gypsum and (gypsum+sand)

Table 3. Variation of Isc as a function of doses used with gypsum

The used material is Gypsum

\begin{tabular}{cc}
\hline Dose $(\%)$ & $\mathrm{I}_{\mathrm{sc}}(\mathrm{A})$ \\
& 0.88 \\
0.000 & 0.55 \\
0.194 & 0.30 \\
0.387 & 0.25 \\
\hline
\end{tabular}

Table 4. Variation of Isc as a function of doses used with gypsum and sand

The used material: Gypsum + Sand

$\begin{array}{cc}\text { Dose }(\%) & \mathrm{I}_{\mathrm{sc}}(\mathrm{A}) \\ 0.000 & 0.88 \\ 0.194 & 0.37 \\ 0.292 & 0.20 \\ 0.387 & 0.02\end{array}$

From table 3, table 4 and fig. 7 we can propose an empirical relation as: 
ISO 9001:2008 Certified

\section{International Journal of Engineering and Innovative Technology (IJEIT)}

\section{Volume 10, Issue 5, November 2020}

$$
I_{s c}=I_{s c 0}-p \cdot D
$$

Where $\mathrm{D}$ is the dose of dust, $\mathrm{p}$ is a constant represent the slope of the curve in fig. 7 , Isc is short circuit current and Isc0 is the short circuit current without dust. D can be calculated as:

$$
D=\frac{\text { Volume of } \text { dust }}{\text { Volume of } b o x} \cdot 100
$$

$\mathrm{p}$ is a constant depends on the type of dust (gypsum, sand, .....), it represents the slope of the curve.

Using table 3 , table 4 and equation (1), the fig. 7 can be represented otherwise (fig. 8)

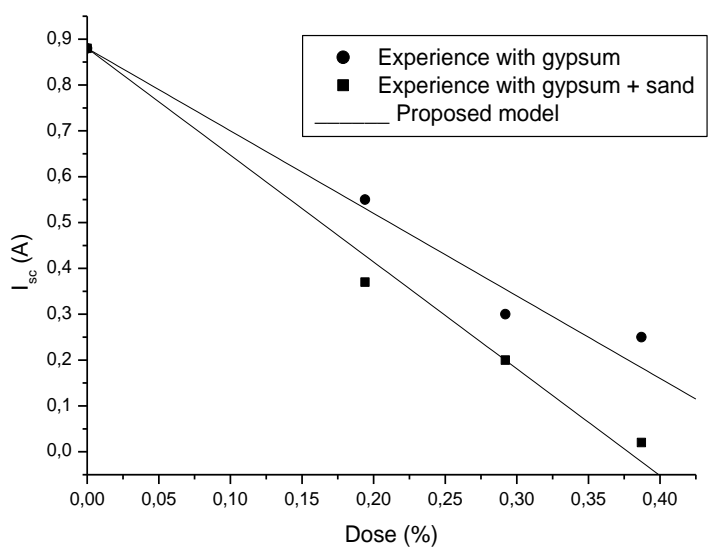

Fig. 8. Variation of $I_{\mathrm{sc}}$ as a function of doses of gypsum and (gypsum+sand) with fit of proposed model in equation (1)

Figure 3 provides the best match for experimental data and figure 4, the gypsum dust constant $\mathrm{p}$ is $1.8 \mathrm{~A}$ and the mixed $\mathrm{p}$ (gypsum+sand) is $2.33 \mathrm{~A}$. This model can also be used for the simulation of other dust forms. Researchers have been developed to calculate the density and size dust distribution in normal plasma operations [23] and density distribution in 3D complex plasma [24]. Different methods have been developed in this area.

\section{CONCLUSION}

The results show that the performance of the PV panels decreases on an alignment of a rise in the dust quantity. A new artificial system is built to investigate the effects of sandstorm in the lab without displacement in the desert regions (Sahara) (doses). A theoretical model is proposed and the difference in PV power for various forms of dust can be studied.

\section{REFERENCES}

[1] M. Amrani Nader and A. Dib, "Implementation of a maximum power point traking (MPPT) Algorithm for photovoltaic (PV) system," J. New Technol. Mater. Vol. 5, no. 1, pp. 11-16, June 2015 .

[2] M. Ali Omar and H. Abdulazez, "Effect of Dust Accumulation on Performance of Photovoltaic Solar Modules in Sahara Environment," J. Basic. Appl. Sci. Res. Vol. 2, no. 11, pp. 11030-11036, 2012.

[3] N. Bouaouadja, S. Bouzid, M. Hamidouche, C. Bousbaa and M. Madjoubi,. "Effects of sand blasting on the efficiencies of solar panels,” Appl Energ, vol. 65, pp. 99-105, 2000.
[4] L. Bennamoun and A. Belhamri, "Study of solar thermal energy in the north region of Algeria with simulation and modeling of an indirect convective solar drying system," Nature \& Technology, vol. 4, pp. 34-40, 2011.

[5] A. Marouani, N.Bouaouadja, Y. Castro and A. Duran, "Effect of the sandstorms on the solar panels," Proc. 1st International Symposium on Innovative Technologies in Engineering and Science, Sakarya, Turkey, 2013, pp: 318-325.

[6] M. Monto and P. Rohit, "Impact of dust on solar photovoltaic (PV) performance: Research status, challenges and recommendations," Renew Sust Energ Rev., vol. 14, pp 3124-3131, 2010.

[7] Ali A. Kazem, Miqdam T. Chaichan and Hussein A. Kazem, "Dust effect on photovoltaic utilization in Iraq: Review article," Renewable and Sustainable Energy Reviews, vol. 37, pp. 734-749, 2014.

[8] S. A. Sulaiman, H. H. Hussain, N. S. H. Nik Leh, and M. S. I.Razali, "Effects of Dust on the Performance of PV Panels," International Journal of Mechanical and Mechatronics Engineering, vol. 5, no. 10, pp. 2021-2026, 2011.

[9] A. Benatiallah, Ali A. Mouly., F. Abidi, D. Benatiallah, A. Harrouz and I. Mansouri, "Experimental study of dust effect in multi-crystal PV solar module," Int. J. Multidiscip. Sci. Eng., vol. 3, Issue 3, pp. 2045-2057, 2012.

[10] J. K Kaldellis and A.Kokala, "Quantifying the decrease of the photovoltaic panels energy yield due to phenomena of natural air pollution disposal," Energy, vol. 35, no. 12, pp. 4862-4869, 2010.

[11] J. K. Kaldellis, P. Fragos and M. Kapsali, "Systematic experimental study of the pollution deposition impact on the energy yield of photovoltaic installations," Renew Energy, vol. 36, no. 10, pp. 2717-2724, 2011.

[12] S. Kumar and P. B. L. Chaurasia, "Experimental study on the effect of dust deposition on solar photovoltaic panel in Jaipur (Rajasthan)," Int. J. Sci. Res., vol. 3, no. 6, pp. 1690-1693, June 2014

[13] M. Mani and R.Pillai, "Impact of dust on solar photovoltaic (PV) performance: research status, challenges and recommendations," Renew. Sustain. Energy Rev., vol. 14, pp. 3124-3131, 2010.

[14] A. Molki, "Dust affects solar cell efficiency," Phys. Educ., vol. 45 , no. 5 , pp. 456-458, 2010.

[15] M. Piliougine, J. Carretero, D. Montiel and P. S_anchez-Friera, "Comparative analysis of the dust losses in photovoltaic modules with different cover glasses," in: Proceedings of 23rd European photovoltaic Solar Energy Conference, pp. 2698-2700, 2008.

[16] S. Kalogirou, R. Agathokleous and Gr. Panayiotou, "On-site PV characterization and the effect of soiling on their performance," Energy, vol. 51, pp. 439-446, 2013.

[17] A. O. Mohamed and A. Hasan, "Effect of dust accumulation on performance of photovoltaic solar modules in Sahara environment," J. Basic Appl. Sci. Res., vol. 2, no. 11, pp. 11030-11036, 2012.

[18] V. K. Sissakian, N. Al-Ansari and S. Knutsson, "Sand and dust storm events in Iraq," Nat. Sci., vol. 5, no. 10, pp. 1084-1094, 2013. 


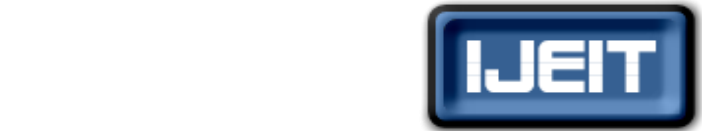

ISSN: 2277-3754

ISO 9001:2008 Certified

International Journal of Engineering and Innovative Technology (IJEIT)

Volume 10, Issue 5, November 2020

[19] M. Saidan, A. Albaali, E. Alasis and J. K. Kaldellis, "Experimental study on the effect of dust deposition on solar photovoltaic panels in desert environment," Renewable Energy, vol. 92, pp. 499-505, 2016.

[20] W. P. West, B. D. Bray and J. Burkart, "Measurement of number density and size distribution of dust in DIII-D during normal plasma operation," Plasma Phys Controlled Fusion, vol. 48, no. 11, pp. 1661-1672, 2006.

[21] V. N. Naumkin, D. I. Zhukhovitskii, V. I. Molotkov, A. M. Lipaev, V. E. Fortov, H. M. Thomas, P. Huber and G. E. Morfill, "Density distribution of a dust cloud in three-dimensional complex plasmas," Phys. Rev. E, vol. 94, no. 3, pp. 033204-1-033204-10, 2016.

[22] J. Buttrago, P. Alvarez, G. Lopez, A. Mujica and F. Sanchez, "Method for determining dust particle density above the ecliptic plane," Planetary and Space Science, vol. 29, no. 2, pp. 137-138, Feb 1981.

[23] H. Kellil, "Improvement and protection of solar panels. Theoretical and experimental study", Doctorate thesis, University of Khenchela, Algeria, July 2020.

[24] H. Kellil, A. Nouiri, T. D. Ounis and H. Bahtoun, "study of solar panel protection by plastic covers against sandstorm in desert regions," Pollution research, vol. 38, no. 2, pp. 271-274, 2019. 